\title{
Implementasi Sekolah Sedekah Sampah untuk Mewujudkan Pengelolaan Sampah Berbasis Filantropi di SMP Muhammadiyah Kota Batu
}

\author{
Idaul Hasanah ${ }^{* 1}$, Husamah², Gina Harventy ${ }^{3}$, Novita Ratna Satiti ${ }^{4}$ \\ ${ }^{1}$ Ahwal Syakshiyyah, Fakultas Agama Islam, dan PSLK Universitas Muhammadiyah Malang \\ 2 Pendidikan Biologi, Fakultas Keguruan dan Ilmu Pendidikan, dan PSLK Universitas Muhammadiyah Malang \\ ${ }^{3}$ Akuntansi, Fakultas EKonomi dan Bisnis, dan PSLK Universitas Muhammadiyah Malang \\ ${ }^{4}$ Manajemen, Fakultas EKonomi dan Bisnis, dan PSLK Universitas Muhammadiyah Malang
}

\section{A R T I C L E I N F O}

\section{Article history:}

Received 20 August 2018 Received in revised form 15 September 2018 Accepted 24 Oktober 2018 Available online 27

November 2018

\section{Kata Kunci:}

Cinta lingkungan, filantropi, Persyarikatan

Muhammadiyah, Sekolah

sedekah sampah

Keywords:

Love of environment,

Muhammadyah

organization, phylantropy,

Sekolah sedekah sampah

\begin{abstract}
A B S T R A K
Sampah menjadi masalah di perkotaan, terlebih tujuan wisata seperti Kota Batu, Jawa Timur. Sebagai upaya penguatan kesadaran sejak dini bagaimana mengatasi permasalahan sampah dan penguatan karakter cinta lingkungan berbasis agama Islam, maka dilakukan pengabdian di SMP Muhammadiyah 2 dan SMP Muhammadiyah 8 Kota Batu. Artikel ini bertujuan mendeskripsikan implementasi program "Sekolah Sedekah Sampah" di SMP Muhammadiyah Kota Batu. Subjek pengabdian ini adalah masingmasing 3 orang guru dan 50 siswa SMP Muhammadiyah 2 dan SMP Muhammadiyah 8 Kota Batu. Pengabdian dilakukan selama delapan bulan dalam bentuk pelatihan, pendampingan, dan praktik langsung (implementasi). Evaluasi keberhasilan pengabdian didasarkan pada proses dan output, yaitu antusiasme peserta, dihasilkannya produk, peningkatan kompetensi peserta dalam pengelolaan sampah, dan produk berupa lingkungan sekolah yang lebih hijau. Hasil evaluasi menunjukkan bahwa rerata kehadiran peserta mencapai 95\%, dihasilkannya logo dan konsep 3S, ada peningkatan kompetensi peserta dalam pengelolaan sampah (pemberlakuan konsep 3S), dan produk berupa lingkungan sekolah yang lebih hijau. Dapat
\end{abstract} disimpulkan bahwa pengabdian masyarakat telah diimplementasikan dengan sangat baik.

Garbage is a problem in urban areas, especially tourist destinations such as Kota Batu, East Java. As an effort to strengthen early awareness about overcome the problem of garbage and strengthening the character of love of environment based on Islamic values, hence done a community service in SMP Muhammadiyah 2 and SMP Muhammadiyah 8 Kota Batu. This article aims to describe the implementation of "Sekolah Sedekah Sampah/3S" program in SMP Muhammadiyah Kota Batu. The subjects of this community service are 3 teachers and 50 students of SMP Muhammadiyah 2 Kota Batu and 3 teachers and 50 students of SMP Muhammadiyah 8 Kota Batu. Community service is done for approximately eight months in the form of training, mentoring, and direct practice (implementation). Evaluation of the success is based on process and output that is the enthusiasm of the participants, the product produced, improvement of competence of participant in waste management, and product of a greener school environment. The results of the evaluation show that the average attendance of participants reaches $95 \%$, the resulting logo and $3 S$ concept, there is an increase of competence of participants in waste management (3S implementation), and the product of a greener school environment. It can be concluded that community service has been implemented very well.

\footnotetext{
* Corresponding author.

E-mail addresses: idaul.hasanah@gmail.ac.id (Idul Hasanah)
} 


\section{Pendahuluan}

Kota Batu merupakan salah satu Kabupaten/Kota di Jawa Timur yang memiliki perkembangan pesat dalam hal sektor pariwisata. Sebagai dampak pesatnya kemajuan pariwisata tersebut, Kota Batu memiliki problem pengelolaan sampah (Hapsari, Dwirianti, \& Trihadiningrum, 2005). Sampah jelas menjadi permasalah serius di Kota Batu yang akan berdampak terhadap kesehatan, kehidupan penduduk, ekonomi, dan kesinambungan pariwisata itu sendiri. Volume sampah di Kota Batu kurang lebih 475 $\mathrm{m}^{3}$ /hari, dimana jumlah ini terus meningkat setiap tahunnya mengingat tingginya angka kunjungan wisata. Besarya sampah yang terangkut hingga sampai ke tempat pembuangan sampah akhir (TPSA) hanyalah $245 \mathrm{~m}^{3}$ /hari. Persentase pemenuhan layanan kebersihan di Kota Batu pun masih mencapai 66\%, karena baru 16 desa/kelurahan yang terlayani sementara 8 desa/kelurahan belum terlayani (Arief, 2013).

Permasalahan sampah semakin menjadi rumit di di Malang Raya (termasuk Kota Batu) karena kecenderungan berkembangnya perilaku konsumtif masyarakat dan apatisnya mereka terhadap persoalan lingkungan di sekitarnya. Masyarakat Kota Batu semakin abai terhadap permasalahan sampah karena memandang bahwa sampah sebagai objek yang tak bermanfaat lagi (Primadi, 2015). Masyarakat Kota Batu dan wisatawan pun banyak yang memiliki kebiasaan membuang sampah sembarangan. Rumah tangga (domestik) sebagai penyumbang sampah terbesar di Kota Batu juga masih menjadi masalah karena tidak adanya kesadaran pemilahan sampah. Sementara itu, penanganan sampah di objek wisata tidak dilakukan secara khusus (Nurhidayati, 2013). Kondisi ini sebagaimana umumnya kenyataan di berbagai tempat/obyek wisata di Indonesia (Darmawi, 2017; Lestari \& Azkha, 2010; Way, Wuisang, \& Supardjo, 2015). Masalah sampah cenderung dipandang remeh sehingga akhirnya sampah tidak pernah selesai (Aprilia, Sunarti, \& Pangestuti, 2017; Naltaru, Purnaini, \& Irsan, 2014).

Berdasarkan permasalahan tersebut, perlu adanya suatu upaya menguatkan masyarakat (dalam konteks yang lebih luas) dapat berperan aktif dalam menangani permasalahan sampah (Primadi, 2015). Mengingat sampah merupakan produk berbagai aktivitas masyarakat, maka secara logis seharusnya disadari bahwa pengelolaan sampah adalah tanggung jawab semua pihak. Sinergi semua pihak merupakan pola ideal dalam menyelesaikan permasalahan sampah (Sudiro, Artiyani, \& Poerwati, 2016). Permasalahan sampah harus pula dipandang tidak hanya sekedar secara teknis mengolah sampah, tetapi juga bagaimana menanganinya secara multi-perspektif, baik sosial, ekonomi, hukum, maupun politik. Berbagai metode dan alternative alternatif solusi berorentasi jangka pendek maupun jangka panjang perlu dilakukan (Rahmawati, 2006). Dalam hal ini, misalnya sampah memiliki potensi ekonomi (Apriliyanti, Soemarno, \& Meidiana, 2015; Rahmatika, 2017) dan penguatan/penanaman semangat filantropi bila dilakukan secara baik dan serius (Effendi, 2017; Mashuri et al., 2016).

Salah satu upaya yang dapat dilakukan terkait permasalahan sampah adalah penyadaran sejak dini melalui pendidikan di sekolah (Hartatik, 2016). Penguatan kesadaran sejak dini akan mendukung tertanamnya akhlak mulia peserta didik secara utuh, terpadu, dan seimbang (Fitroh \& Sari, 2015). Usia sekolah adalah usia efektif untuk memberikan kesadaran akan pentingnya menjaga lingkungan. Pendidikan merupakan salah satu upaya potensial dalam mengatasi persoalan lingkungan. Pendidikan melalui sekolah akan lebih efektif menyentuh dan melekat pada peserta didik. Kesadaran lingkungan merupakan bagian dari pendidikan karakter. Karakter siswa untuk berlingkungan bersih, karakter membuang sampah ditempatnya, karakter membuang sampah sesuai jenisnya serta karakter siswa bersikap bijak bijak dalam pengelolaan sampah. Pendidikan karakter dibentuk melalui pendidikan nilai (Hudha, Husamah, \& Hadi, 2011; Ilma \& Wijarini, 2017; Setiawan \& Arifendi, 2016; Sidik \& Susilowati, 2013).

Permasalahan-permasalahan yang diuraikan di atas, juga dihadapi oleh sekolah mitra (SMP Muhammadiyah 2 dan SMP Muhammadiyah 8 Batu). Sekolah-sekolah tersebut memiliki keberagaman siswa dapat dilihat dari tingkat beragamnya latar belakang ekonomi. Terutama di SMP Muhammadiyah 2 dan SMP Muhammadiyah 8 Batu, terdapat siswa yang berasal dari keluarga menengah ke atas, namun banyak yang berasal dari keluarga menengah ke bawah dan bahkan ada yang tinggal di Panti Asuhan Muhammadiyah. Berdasarkan permasalahan yang ditemui baik di SMP Muhammadiyah 2 dan SMP Muhammadiyah 8, untuk menciptakan lingkungan sekolah yang green, cleen and comfortable ditemukan permasalah sebagai berikut: (1) Masih kurangnya kesadaran siswa akan bahaya kerusakan lingkungan yang disebabkan sampah. Adanya sampah di lingkungan sekolah dan lingkungan rumah yang belum dikeola dengan baik dan berpotensi merusak lingkungan. (2) Masih kurangnya sarana pendukung demi terciptanya lingkungan sekolah yang green, cleen and comfortable. (3) Adanya siswa dari keluarga ekonomi rendah dan siswa penghuni panti asuhan yang perlu uluran bantuan. Kondisi ini digabungkan dengan pendidikan karakter memunculkan ide program pengabdian dengan konsep Sekolah Sedekah Sampah (3S). 
Solusi yang ditawarkan untuk menyelesaikan permasalahan di atas adalah dengan memunculkan konsep Sekolah Sedekah Sampah. Ide program ini merupakan gabungan permasalahan sekolah dengan pendidikan karakter. Sekolah Sedekah Sampah merupakan program yang tepat untuk diterapkan untuk menyelesaikan permasalahan mitra. Ada dua alasan yang dapat dipaparkan: pertama, dua sekolah yang menjadi mitra adalah sekolah di bawah persyarikatan Muhammadiyah. Kedua, Pimpinan Pusat Muhammadiyah melalui Majelis Lingkungan Hidup sedang menggerakkan program Sedekah Sampah.

Sedekah sampah awalnya adalah gerakan yang dicanangkan Pimpinan Pusat Muhammadiyah ini adalah menanamkan kebiasaan umat untuk berperilaku bijak dalam mengelola sampah dan melestarikan lingkungan hidup sekaligus meningkatkan amal kebaikan melalui gerakan sedekah sumberdaya sampah (MLH-PPMUH, 2016). Tim pengabdian melakukan berbagai modifikasi dan pengembangan terhadap program tersebut dengan tujuan khususnya adalah siswa dan warga sekolah, sehingga dihasilkanlah tema Sekolah Sedekah Sampah (3S). Oleh karena itu, artikel ini bertujuan mendeskripsikan implementasi Sekolah Sedekah Sampah (3S) untuk mewujudkan pengelolaan sampah berbasis filantropi di SMP Muhammadiyah Kota Batu.

\section{Metode}

Sebelum memulai kegiatan magang, Mahasiswa mendapat Workshop ICE. Workshop ini bertujuan memberi pengarahan kepada peserta magang sebelum ditempatkan di tempat magang. Pengarahan yang diberikan meliputi jadwal kerja, penempatan bagian dan pembimbingan mahasiswa dan menekankan kepada mahasiswa magang khususnya untuk bersikap disiplin baik dalam hal waktu maupun dalam melakukan segala tugas yang diberikan atasan maupun pegawai yang ada di bagiannya masing-masing.

Pelaksanaan magang di kantor "Bintang 5 Production" yang dilaksanakan selama 5 Minggu. Pelaksaan Magang dimulai pada tanggal 8 April 2018 Sampai dengan Tanggal 11 Mei 2018. Jam kerja pada hari Senin sampai Jumat mulai pukul 09.30 WIB sampai dengan pukul 12.30 WIB. Selama proses kegiatan magang Mahasiswa ditempatkan pada bagian Design dan EO. Jadwal Jam Kerja di Kantor Dinas Sosial dan Tenaga Kerja Surabaya: (a) Senin - Jumat, (b) Jam Masuk mulai pukul 09.30 WIB sampai dengan 12.30 WIB

Berdasarkan pada jadwal pelaksanaan kegiatan magang yang telah disepakati oleh CV. Bintang Lima Mahardikka dan Universitas PGRI Madiun maka mahasiswa diberi tanggung jawab pada bagian Design dan EO selama 33 hari, untuk itu mahasiswa harus dapat beradaptasi dengan lingkungan kerja di bagian tersebut. Peraturan yang harus dipatuhi oleh peserta magang sebagai berikut: (a) Hadir setiap hari Senin - Jumat pada pukul 09.30 WIB, (b) Istirahat pukul 12.00 WIB - 13.30 WIB, (c) Jika ada kepentingan dan harus meninggalkan kantor harus meminta izin terlebih dahulu kepada yang bersangkutan, (d) Berpakaian Sopan dan rapi, celana panjang dan atasan berkerah.

\section{Hasil dan pembahasan}

Gambaran tentang jalannya kegiatan pengabdian dan IPTEK yang ditransfer kepada mitra diuraikan sebagai berikut. Kegiatan sosialisasi (penyampaian materi pengantar dan penyamaan persepsi) dilakukan agar tim memiliki kesepahaman dan persepsi yang sama dengan sekolah terhadap masalahmasalah yang dihadapi dan bagaimana mengatasinya. Kegiatan ini akan menjadi titik awal yang sangat penting guna mengetahui peran dan tanggung jawab masing-masing pihak dalam menyelesaikan masalah yang dihadapi. Pada tahap ini juga dilakukan identifikasi jenis-jenis dan sumber sampah yang ada di sekolah sehinga akan lebih memudahkan dalam pengelolaan atau penanganannya.

Pembekalan dimaksudkan untuk memberikan pemahaman kepada siswa mengenai berbagai persoalan lingkungan di masa kini dan alternatif solusi yang bisa dilakukan untuk mengurangi dampak negatifnya. Juga mengenai pengelolaan sampah, filantropi dengan semangat al-Ma'un serta pengelolaan 3S. Pada pembekalan ini disampaikan dua materi, yaitu pertama, konsep 3S yang merupakan konsep pengelolaan sampah berbasis filantropi yang disampaikan oleh Husamah, S.Pd., M.Pd. Pada sesi ini disampaikan tentang konsep sekolah sedekah sampah. Hingga saat ini yang banyak dilakukan oleh masyarakat adalah bank sampah, namun yang kembangkan majelis lingkungan Hidup PP Muhammadiyah adalah sedekah sampah. Sekolah dapat menerapkan sedekah sampah yang melibatkan siswa dan guru. Siswa dan guru mengumpulkan sampah yang dihasilkan di sekolah maupun yang dihasilkan di rumah untuk disedekahkan dan hasilnya dikelola untuk siswa tidak mampu atau untuk menunjang pendidikan sekolah.

Materi kedua disampaikan oleh Idaul Hasanah, S.Ag., M.HI yang menyampaikan persoalanpersoalan lingkungan serta alternatif solusinya. Mengantisipasi semakin memanasnya lingkungan (sekolah) dilakukan dengan menanam tanaman di berbagai tempat, meski dengan metode taman vertikal. 
Terkait dengan semakin massifnya produksi sampah, siswa siswi diajak untuk bertindak bijak, seperti membawa tas sendiri ketika berbelanja, menggunakan popok kain (menspad) ketika menstruasi sebagai pengganti pembalut sekali pakai. Berhadapan dengan problema sampah yang semakin banyak, siswa diajak untuk memilah sampah sesuai jenisnya, sampah organik dan sampah an-organik agar dapat diproses lebih maksimal. Sampah organik bisa diolah menjadi kompos, sampa han organik bisa dimanfaatkan kembali, dibuat kerajinan atau didaur ulang dan menjadi bahan baku produk-produk lain yang bermanfaat. Adapun dokumentasi kegiatan ini sebagaimana disajikan pada Gambar 1 dan Gambar 2 .

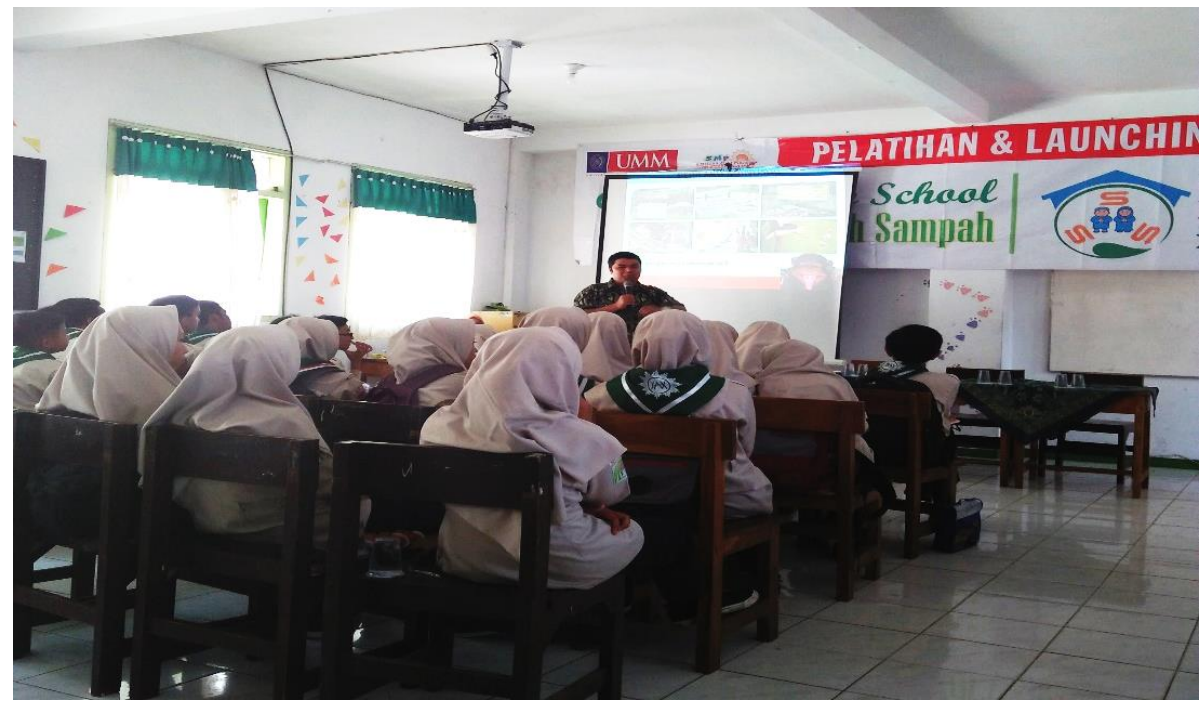

Gambar 1. Dokumentasi Kegiatan Sosialisasi Sekolah Sedekah Sampah (3S)

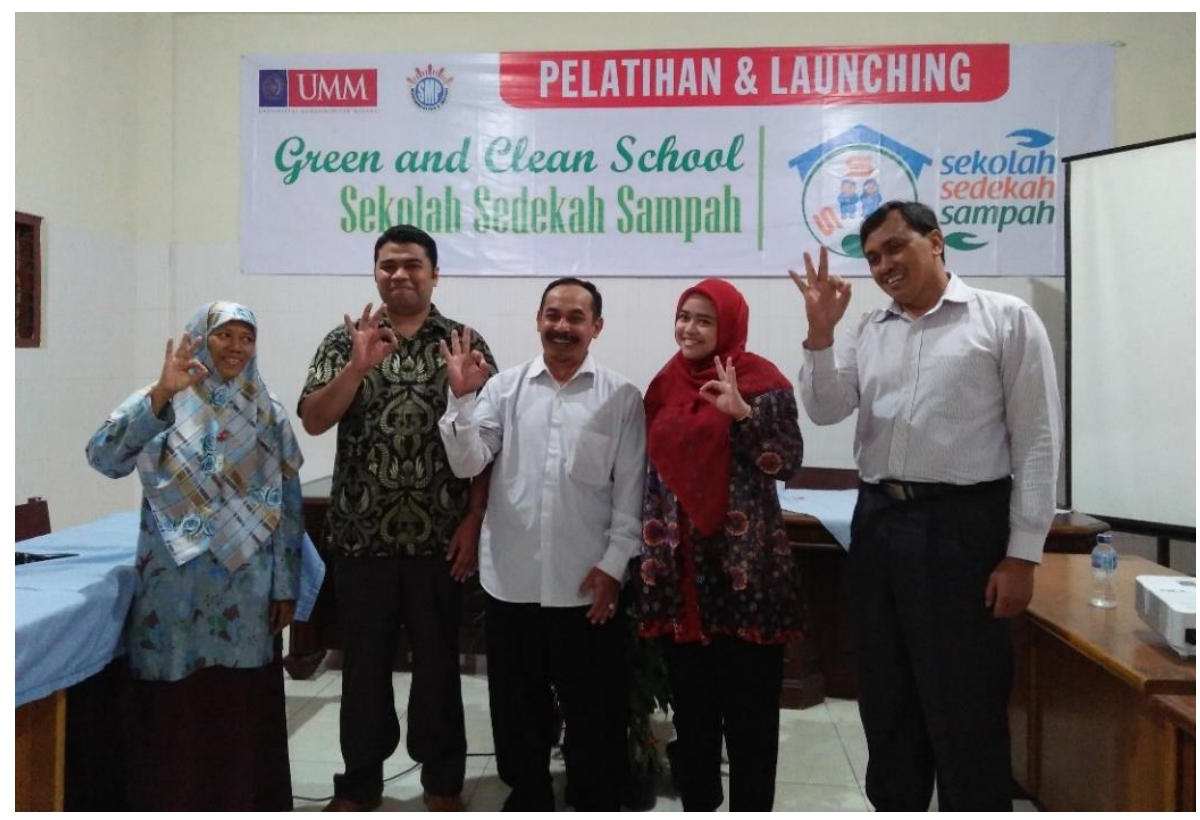

Gambar 2. Dokumentasi bentuk komitmen dan janji sekolah mengimplementasikan Konsep 3S

Para siswa dan guru yang terlibat dalam kegiatan pengabdian ini sangat antusias, mereka aktif mengikuti berbagai rangkaian kegiatan, antusias menyimak dan aktif bertanya kepada kedua pemateri (sebagaimana disajkan pada Tabel 1). Selanjutnya mereka berkomitmen untuk menerapkan hasil yang diperoleh dalam kegiatan ini di sekolah dan mengharapkan adanya pendampingan dari tim pengabdian. 
Tabel 1. Peserta pengabdian

\begin{tabular}{|c|c|c|c|}
\hline No & Peserta & Jumlah (orang) & Keterangan \\
\hline 1 & $\begin{array}{l}\text { Guru, kepala sekolah, dan } \\
\text { wakil kepala sekolah }\end{array}$ & 6 & $\begin{array}{l}\text { Masing-masing } 3 \text { orang guru dari setiap } \\
\text { sekolah; peserta Aktif }\end{array}$ \\
\hline 2 & Siswa & 100 & $\begin{array}{l}\text { Masing-masing } 50 \text { orang siswa dari setiap } \\
\text { sekolah; peserta aktif; tingkat kehadiran } 95 \%\end{array}$ \\
\hline 2 & Tim Pengabdi & 3 & Aktif \\
\hline 3 & Mahasiswa & 2 & Aktif \\
\hline
\end{tabular}

Kegiatan ini dikemas dalam bentuk pelatihan dan pendampingan secara berkala. Kegiatan ini bertujuan untuk memberikan bekal kepada para siswa sebagai "amil" (pengelola Sekolah Sedekah Sampah). Materi pelatihan berupa pengetahuan tentang konsep Sekolah Sedekah Sampah, pengetahuan mengenai persoalan lingkungan terutama yang disebabkan oleh sampah, dan pemahaman serta ketrampilan tentang pemilahan sampah; baik sampah organik, sampah anorganik serta pemilahan jenisjenis sampah yang dapat dimanfaatkan kembali. Mereka juga didampingi bagaimana mengimplementasikan kegiatan 3S ini. Adapun logo 3S dapat dilihat pada Gambar 3.

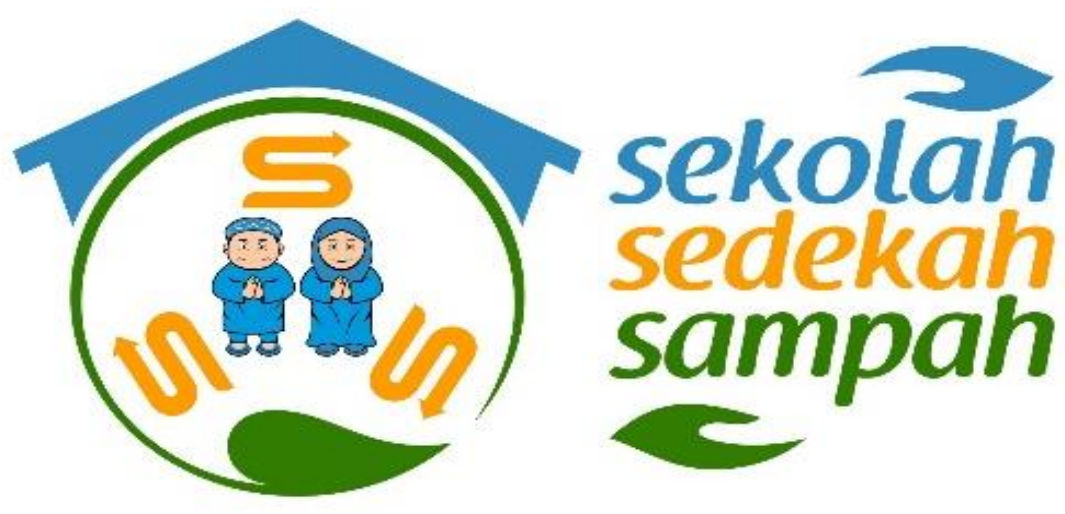

Gambar 3. Logo Sekolah Sedekah Sampah/3S (Logo Berhak Cipta)

Sebagai bekal para "amil", maka tim memberikan rambu-rambu yang dapat mereka jadikan pedoman dalam pelaksanaan kegiatan. Rambu-rambu tersebut berupa pertanyaan-pertanyaan penting, yaitu (1) Pertanyaan 1: Apa itu Sekolah Sedekah Sampah? Jawabannya adalah: Sekolah yg menerapkan sebuah program, dimana para siswa, guru, orang tua, dan masyarakat yg peduli akan memilah sampah mereka, mengumpulkan dan mensedekahkan ke sekolah. Selanjutnya Amil yang berasal dari siswa terpilih di bawah bimbingan guru, akan menjual sampah yang terkumpul (kerjasama dengan pengumpul), dan dana hasil penjualan digunakan untuk menyantuni para siswa kurang mampu di sekolah (ada banyak anak yatim piatu dan dari keluarga kurang mampu di sekolah-sekolah di sekitar kita). (2) Pertanyaan 2: Benarkah sepenuhnya akan disedekahkan? Jawabannya adalah: Benar! $100 \%$ hasil penjualan dan dana yg terkumpul akan digunakan untuk menyantuni siswa yg kurang mampu di sekolah. (3) Pertanyaan 3: Program ini telah dilakukan dimana? Jawabannya adalah: Sebagai tahap perintisan dan pilot project, program ini diterapkan di SMP Muhammadiyah 2 Kota Batu dan SMP Muhammadiyah 8 Kota Batu. (4) Pertanyaan 4: Kami masyarakat umum, bagaimana cara menjadi donatur/penderma? Jawabannya adalah: Caranya simpel saja, a) Pilahlah sampah Anda. Sementara program ini baru menerima 2 jenis sampah (sampah kertas dan plastik). b) Kemas dengan rapi dalam kardus atau kantong-kantong plastik/karung bekas. c) Serahkan ke kantor sekolah. Ingat, sempurnakan ibadah dan sedekah Anda dengan memudahkan para Amil dan penerima manfaat. Pilah, kemas dengan rapi, setorkan langsung, dan Anda akan tahu berapa nilai nominal dari sampah Anda. (5) Pertanyaan 5: Apakah ada cara lain menyedekahkan sampah kami? Jawabannya adalah: Program ini masih perintisan. Tenaga masih terbatas. Jadi kami belum mampu menjemput ke tempat-tempat para donatur. Kuatkan niat Anda, pilah sampah Anda, jual saja ke pengepul yang lewat. Hasil penjualan bisa diserahkan kepada kami untuk selanjutnya kami salurakan ke sekolah mitra. (6) Pertanyaan 6: Apakah saya boleh mengetahui secara transparan penggunaan dana ini? Jawabannya adalah: Sangat boleh. jika dibutuhkan, kami akan memberikan tanda bukti penyerahan donasi, dan tanda bukti (foto dan bukti lain) bahwa donasi Anda telah diterima siswa. (7) Pertanyaan 7: Sampah apa saja yg bisa kami sedekahkan? Jawabannya adalah: Sementara kami hanya menerima sampah 
plastik dan kertas. Anda juga dapat menyedahkan dalan bentuk dana (ingat, semua transparan dan akan dilaporkan setelah diserahkan).

Penyelesaian permasalahan sampah tidak dapat hanya mengandalkan solusi teknis parsial, tetapi harus menggunakan solusi holistik-komperhensif. Pendekatan interdisipliner yang salah satu diantaranya dan yang utama adalah agama. Nuansa teologi dalam penanganan lingkungan telah menjadi pendekatan baru untuk mengatasi masalah lingkungan dan termasuk di sana adalah sampah (Fatah, Taruna, \& Purnaweni, 2013).

Sekolah Sedekah Sampah adalah program yang diinisiasi PSLK UMM, merupakan kelanjutan program Sedekah Sampah Majelis Lingkungan Hidup Pimpinan Pusat Muhammadiyah. Program Sekolah Sedekah Sampah dilakukan oleh para siswa, guru, orang tua, dan masyarakat yang peduli akan memilah sampah mereka, mengumpulkan dan mensedekahkan ke sekolah. Selanjutnya Amil yang berasal dari siswa terpilih di bawah bimbingan guru, akan menjual sampah yang terkumpul (kerjasama dengan pengumpul), dan dana hasil penjualan digunakan untuk menyantuni para siswa kurang mampu di sekolah (ada banyak anak yatim piatu dan dari keluarga kurang mampu di sekolah-sekolah di sekitar kita).

Hingga saat ini yang banyak dilakukan oleh masyarakat adalah bank sampah (Apriliyanti et al., 2015; Rahmatika, 2017), namun yang kembangkan majelis lingkungan Hidup PP Muhammadiyah adalah sedekah sampah. Sekolah dapat menerapkan sedekah sampah yang melibatkan siswa dan guru. Siswa dan guru mengumpulkan sampah yang dihasilkan di sekolah maupun yang dihasilkan di rumah untuk disedekahkan dan hasilnya dikelola untuk siswa tidak mampu atau untuk menunjang pendidikan sekolah (MLH-PPMUH, 2016).

Gerakan 3S memiliki target sebagai berikut, yaitu (1) adanya kesadaran dan perilaku aktif umat (khususnya siswa dan warga sekolah) dalam mengelola lingkungan, terutama dalam mengelola sampah yang tepat dan benar; (2) adanya gerakan shadaqah sumberdaya sampah di lembaga pendidikan (sekolah); (3) adanya sumber pendanaan alternatif bagi amal usaha (lembaga pendidikan) untuk kegiatan dakwah dan sosial (Mashuri et al., 2016).

Gerakan 3S ini berimplikasi pada terlaksananya upaya pengembangan budaya dan kebiasaan yang ramah lingkungan sejak dini, secara khusus di sekolah, di rumah, maupun dalam lingkungan pergaulan mereka. Melalui program $3 \mathrm{~S}$ ini para siswa tidak hanya mendapatkan pelajaran atau pengetahuan semata, namun meliputi juga praktik nyata serta tertanamnya kepekaan sosial dan penanaman ajaran agama. Siswa juga diajarkan membersihkan lingkungan rumah dan sekolah secara bijak agar terbebas dari aneka sampah-sampah plastik, membiasakan hidup bersih, dan memberi makna pada aktivitas itu karena beriringan dengan konsep kepekaan sosial atau sedekah.

Gerakan 3S ini memberikan penguatan bahwa ajaran Islam sejalan dengan upaya menyelesaikan problematika lingkungan berbasis filantrofi. Islam memandang lingkungan sebagai bagian tak terpisahkan dari keimanan seseorang Muslim (manusia) terhadap Allah SWT (Musthofa et al., 2017). Perilaku tersebut merupakan cerminan akhlak dan keimanan, sehingga memelihara lingkungan merupakan kewajiban yang setara dengan kewajiban ibadah sosial yang lainnya. Kita semua tentu meyakini kebenaran cara pandang Islam yang tidak mempertentangkan agama dengan ilmu pengetahuan dan teknologi (Husamah \& Setiawan, 2016). Ilmu tidak bersifat sekuler, bahkan nilai-nilai agama selalu menjiwai ilmu dan teknologi. Menurut pandangan Islam, hidup manusia tidaklah terpisah dari ekosistemnya, melainkan integral. Manusia adalah pengemban amanat Allah SWT untuk menjaga dan memelihara alam demi kepentingan kemanusiaan (Assaad, 2011).

Kegiatan ini memiliki potensi keberlanjutan yang sangat tinggi. Hal ini karena civitas akademika sekolah sangat antusias, terlibat langsung, berkomitmen (dalam bentuk penyediaan fasilitas dan adanya kebijakan), serta respon positif wali murid. Ketika siswa memiliki antusiasme tinggi, pihak sekolah mendukung penuh, dan para wali murid juga memberikan respon positif, maka kebijakan atau programprogram kreatif serta inovatif yang diterapkan di sekolah akan berjalan dengan baik, bahkan memiliki potensi besar untuk berhasil sesuai dengan target dan tujuan yang ditetapkan.

\section{Simpulan dan saran}

Program pengabdian telah terlaksana dengan baik, sesuai dengan target. Kegiatan yang telah dilakukan oleh tim pengabdian adalah (1) sosialisasi dan pembekalan Sekolah Sedekah Sampah dan (2) Pendampingan implementasi dan penyempurnaan konsep Sekolah Sedekah Sampah. Kegiatan pengabdian ini memiliki manfaat bagi sekolah, khususnya dalam membantu sekolah mewujudkan green and clean school serta menanamkan rasa peduli permasalahan sampah bagi siswa. Oleh karena itu, perlu kegiatankegiatan pengabdian dengan tema atau isu terkait yang bersifat pengembangan sehingga sekolah akan semakin merasakan manfaatnya. 


\section{Daftar Rujukan}

Aprilia, E. R., Sunarti, S., \& Pangestuti, E. (2017). Pengaruh daya tarik wisata dan fasilitas layanan terhadap kepuasan wisatawan di Pantai Balekambang Kabupaten Malang. Jurnal Administrasi Bisnis (JAB), 51(2), 16-21.

Apriliyanti, P. D., Soemarno, S., \& Meidiana, C. (2015). Evaluasi kinerja bank sampah Kartini Mandiri Desa Pesanggrahan Kota Batu. J-PAL, 6(2), 143-152.

Arief, S. (2013). Pengelolaan sampah Malang Raya menuju pengelolaan sampah terpadu yang berbasis partisipasi masyarakat. Jurnal Humanity, 8(2), 195-208.

Assaad, I. (2011). Sambutan deputi komunikasi lingkungan dan pemberdayaan masyarakat, Kementerian Lingkungan Hidup. In Teologi Lingkungan (Etika Pengelolaan Lingkungan dalam Perspektif Islam) (II). Jakarta: Deputi Komunikasi Lingkungan dan Pemberdayaan Masyarakat Kementerian Lingkungan Hidup dan Majelis Lingkungan Hidup Pimpinan Pusat Muhammadiyah.

Darmawi, A. (2017). Potensi timbulan sampah pada objek pariwisata baru di Kabupaten Bantul Yogyakarta. Jurnal Penelitian Teknologi Industri, 9(1), 61-71.

Effendi, F. A. (2017). Penanaman pendidikan karakter peduli lingkungan melalui pemanfaatan sampah rumah tangga di Majelis Taklim Andalusia Kelurahan Kober, Kecamatan Purwokerto Barat, Kabupaten Banyumas. IAIN Purwokerto.

Fatah, A., Taruna, T., \& Purnaweni, H. (2013). Konsep pengelolaan sampah berbasis teologi. Jurnal Ilmu Lingkungan, 11(1), 84-91.

Fitroh, S. F., \& Sari, E. D. N. (2015). Dongeng sebagai media penanaman karakter pada anak usia dini. Jurnal PG-PAUD Trunojoyo, 2(2), 95-105.

Hapsari, Y. P., Dwirianti, D., \& Trihadiningrum, Y. (2005). Kajian sistem pengangkutan sampah di Kota Batu. In Prosiding Seminar Nasional Manajemen Teknologi II. Program Studi MMT-ITS.

Hartatik, H. (2016). Pengaruh gerakan jumput sampah terhadap pendidikan karakter siswa dan pemeliharaan kebersihan lingkungan sekolah di SD NU Kepanjen Kabupaten Malang. Jurnal Inspirasi Pendidikan, 6(1), 827-834.

Hudha, A. M., Husamah, H., \& Hadi, S. (2011). Pendampingan pengembangan perangkat pembelajaran laboratorium untuk menunjang pelaksanaan KTSP bagi guru IPA Biologi SMP Muhammadiyah 1 Malang. Jurnal Dedikasi, 8, 43-51.

Husamah, H., \& Setiawan, A. (Eds.). (2016). Pemahaman lingkungan secara holistik. Malang: UMM Press \& PSLK UMM.

Ilma, S., \& Wijarini, F. (2017). Developing of environmental education textbook based on local potencies. JPBI (Jurnal Pendidikan Biologi Indonesia), 3(3), 194-201.

Lestari, Y., \& Azkha, N. (2010). Perilaku pengelolaan sampah pada penjual makanan jajanan dan pengunjung wisata di Pantai Padang. Jurnal Kesehatan Masyarakat, 4(2), 97-102.

Mashuri, M., Maulida, T., Hasanah, I., Husamah, H., Harventy, G., \& Satiti, N. R. (2016). Go green \& clean school melalui diet sampah. Malang, Indonesia: UMM Press \& PSLK UMM.

MLH-PPMUH. (2016). Panduan gerakan shodaqoh sampah warga Muhammadiyah. Jakarta: PP Muhammadiyah.

Musthofa, Z. A., Husamah, H., Hudha, A. M., Muttaqin, T., Hasanah, I., \& Setyawan, D. (2017). Mengurai sengkarut bencana lingkungan (Refleksi jurnalisme lingkungan \& deep ecology di Indonesia). Malang: 
UMM Press \& PSLK UMM.

Naltaru, M. S., Purnaini, R., \& Irsan, R. (2014). Perencanaan sistem pengelolaan sampah di kawasan wisata Bukit Kelam Kabupaten Sintang. Pontianak.

Nurhidayati, S. E. (2013). Studi evaluasi penerapan prinsip community based tourism (CBT) sebagai pendukung agrowisata berkelanjutan. Surabaya.

Primadi, H. B. (2015). Perancangan galeri karya sampah anorganik di Kota Malang (Tema: critical regionalism). UIN MALIKI.

Rahmatika, P. H. W. (2017). Pemanfaatan Bank Sampah Malang (BSM) sebagai sumber belajar budaya bersih siswa SDN Kauman 1 Malang. UIN MALIKI Malang.

Rahmawati, R. T. (2006). Strategi pengelolaan sampah di Kota Malang (Studi dinas kebersihan Kota Malang). Malang.

Setiawan, R., \& Arifendi, R. F. (2016). Penggunaan chabi (charming dustbin) dan keranjang takakura sebagai upaya meningkatkan kepedulian lingkungan terhadap anak usia sekolah dasar. JPBI (Jurnal Pendidikan Biologi Indonesia), 2(3), 215-221.

Sidik, S., \& Susilowati, S. (2013). Desain media edukasi animasi interaktif cara pemanfaatan limbah sampah berbasis macromedia flash 8. Jurnal Techno Nusa Mandiri, 10(1), 195-206.

Sudiro, S., Artiyani, A., \& Poerwati, T. (2016). Pengelolaan sampah permukiman wilayah Malang Barat berbasis karakteristiknya. In TEMU ILMIAH IPLBI 2016 (pp. 77-80).

Way, I. H., Wuisang, C. E. V, \& Supardjo, S. (2015). Analisis kebutuhan prasarana dan sarana pariwisata di Danau Uter Kecamatan Aitinyo Kabupaten Masybrat Propinsi Papua Barat. Manado. 